\title{
Surface Modification of Macroporous Matrix for Immobilization of Lipase for Fructose Oleic Ester Synthesis
}

\author{
Hani Hilmanto, Chusnul Hidayat*, Pudji Hastuti \\ Graduate Program on Estate Crop Product Technology, Faculty of Agricultural Technology \\ Universitas Gadjah Mada, Jl. Flora, Bulaksumur, Yogyakarta 55281, Indonesia
}

Received: 21st December 2015; Revised: 23rd February 2016; Accepted: $14^{\text {th }}$ April 2016

\section{Abstract}

The objective of this research was to modify the matrix surfaces to obtain both hydrophobic matrix (HM) and hydrophilic-hydrophobic matrix (HHM) for enzymatic synthesis of fructose oleic ester (FOE). The modification was performed by the attachment of 2-phenylpropionaldehyde (PPA) and PPA followed by polyethyleneimine (PEI) for HM and HHM, respectively. The results from FT-IR analysis showed that the peak of stretching vibration of $\mathrm{NH}_{2}$ bond decreased and it was followed by an increase of the peak vibration of $-\mathrm{C}=\mathrm{N}-$ bond at wave number $1667 \mathrm{~cm}^{-1}$. The peak of bending vibrations of the $\mathrm{C}=\mathrm{C}$ bond also increased. It indicated that PPA was successfully attached on matrix. For HHM, an increase in the peak area of $\mathrm{NH}_{2}$ bond indicated that PEI was also successfully attached on the matrix. The optimum conditions of lipase adsorption were obtained at buffer $\mathrm{pH} 7$ containing $0.5 \mathrm{M} \mathrm{NaCl}(9.27$ $\mathrm{mg}$ protein/g matrix) and without $\mathrm{NaCl}$ (9.23 $\mathrm{mg}$ protein/g matrix) for $\mathrm{HM}$ and HHM, respectively. For FOE synthesis, the best immobilized lipase concentration was about $8 \%$ and $6 \%$ for HM and HHM, respectively. The optimum time of esterification was $24 \mathrm{~h}$ and $18 \mathrm{~h}$ for HM and HHM, respectively, in which the yields were $75.96 \%$ and $85.29 \%$, respectively. The immobilized lipase could be used up to 3 cycles of esterification reaction. Copyright (C) 2016 BCREC GROUP. All rights reserved

Keywords: fructose oleic ester; emulsifier; hydrophobic matrix; hydrophilic-hydrophobic matrix; lipase

How to Cite: Hilmanto, H., Hidayat, C., Hastuti, P. (2016). Surface Modification of Macroporous Matrix for Immobilization of Lipase for Fructose Oleic Ester Synthesis. Bulletin of Chemical Reaction Engineering \& Catalysis, 11 (3): 339-345 (doi:10.9767/bcrec.11.3.573.339-345)

Permalink/DOI: http://dx.doi.org/10.9767/bcrec.11.3.573.339-345

\section{Introduction}

Sugar fatty acid esters are biodegradable and non-toxic emulsifier, which have application in numerous areas including pharmaceuticals, cosmetics, detergents and food industry [1]. Among sugar fatty acid ester, fructose fatty acid esters possess higher interfacial tension values than the other sugar fatty acids [2].

* Corresponding Author.

E-mail: chusnul@gadjahmada.edu (C. Hidayat) Telp: +62-274-549650, Fax: +62-274-549650
The use of enzyme for the production of sugar fatty acid ester is an attractive approach since enzymatic catalysis in non-aqueous media allows obtaining pure product due to enzyme specificity [3]. Lipase immobilization on a surface of matrix through hydrophobic interaction has been reported [4-7]. In the absence of interfaces, lipase contains a hydrophobic oligopeptide (lid) that covers its active site and causes inaccessible for the substrates. In the presence of hydrophobic interface, a conformational rearrangement occurs, turning the 'closed form' into 'open form' [8]. Taking advantage of this catalytic mechanism, the interfacial adsorption of 
lipase on hydrophobic matrix (HM) has been developed as a popular strategy to prepare the immobilized lipase with high catalytic activity [9]. However, the solubility problems between sugar and free fatty acid as substrates still occurs leading in many cases in lowering substrate conversion [10].

The objectives of this research were to obtain a modified macroporous matrix for the immobilization of lipase to enhance the reaction to overcome the disadvantage of low solubility of fructose in oleic acid, and to obtain the optimum condition of lipase immobilization. This research was performed by modifying the surface of the matrix in order to have a hydrophobic surface by the addition of 2phenylpropionaldehyde (PPA). Another modification of the matrix was performed by the addition of glutaraldehyde, followed by the addition of polyethyleneimine (PEI), and PPA to increase the hydrophilic character that can facilitate the dissolution of the substrate fructose and oleic acid. The re-usability of the immobilized lipase was also investigated.

\section{Materials and Method}

\subsection{Materials}

Macroporous Amberlite IRA-96 free base, lipase from Candida rugosa, glutaraldehyde, polyethyleneimine, and olive oil were obtained from Sigma-Aldrich (St. Louis, MO, USA). Fructose, sodium chloride, and 2phenylpropionaldehyde were obtained from Merck KGaA (Darmstadt, Germany). Oleic acid was obtained from ApplyChem.

\subsection{Modification of matrix for enzyme im- mobilization}

Two g matrix was soaked in buffer $\mathrm{pH} 12$ and incubated at $30{ }^{\circ} \mathrm{C}$ for $2 \mathrm{~h}$. Matrix was separated and dried prior to modification. The first modification was carried out by addition of $12.5 \%$ PPA in methanol (v/v). The mixture was kept in the water bath at $30{ }^{\circ} \mathrm{C}$ for $2 \mathrm{~h}$. The second modification was carried out by addition of $2 \%$ glutaraldehyde in buffer $\mathrm{pH} 12(\mathrm{v} / \mathrm{v})$. The mixture was kept in the water bath at $30^{\circ} \mathrm{C}$ for $1 \mathrm{~h}$. The matrix was filtered, and then $1 \% \mathrm{PEI}$ in methanol (w/v) was added. The mixture was kept in water bath at $30^{\circ} \mathrm{C}$ for $4 \mathrm{~h}$. The matrix was dried at $50{ }^{\circ} \mathrm{C}$ for $12 \mathrm{~h}$. Then $12.5 \%$ PPA in methanol (v/v) was added into matrix. The mixture was kept in water bath for $2 \mathrm{~h}$ at 30 ${ }^{\circ} \mathrm{C}$. FT-IR analysis was performed to investigate the effect of both activation and modification of matrices.

\subsection{Immobilization of lipase}

For the effect of salt concentration on the immobilized lipase, $100 \mathrm{mg}$ of modified matrix was added into $2 \mathrm{~mL}$ lipase $(5 \mathrm{mg} / \mathrm{mL})$ in buffer $\mathrm{pH} 7$ containing various salt concentrations $(0$, $0.5,1,1.5,2 \mathrm{M})$. Mixture was mixed in water bath at $37{ }^{\circ} \mathrm{C}$ for $1 \mathrm{~h}$ at 150 strokes/min. The matrix was then filtered and stored at low temperature until use. For the effect of the immobilization time, $100 \mathrm{mg}$ of modified matrix was added into $2 \mathrm{~mL}$ lipase $(5 \mathrm{mg} / \mathrm{mL})$ in buffer $\mathrm{pH} 7$ containing $0.5 \mathrm{M} \mathrm{NaCl}$. Mixture was mixed in water bath at $37{ }^{\circ} \mathrm{C}$ for various reaction time $(10,30,60,120$, and $180 \mathrm{~min})$ at 150 strokes / min. The matrix was then filtered and stored at low temperature until use.

\subsection{Protein determination}

Protein content was determined according to the Bradford method [11] using bovine serum albumin (BSA) as a standard.

\subsection{Assay of hydrolytic activity}

The hydrolytic activity of the immobilized lipase was determined by adding the immobilized lipase into olive oil $60 \%(\mathrm{v} / \mathrm{v})$ in isooctane. Mixture was incubated at $37{ }^{\circ} \mathrm{C}$ for $20 \mathrm{~min}$. Then the sample was chilled in ice bath for $5 \mathrm{~min}$. The produced fatty acids were analysed by adding sample into $1.8 \mathrm{ml}$ isooctane, and $0.4 \mathrm{~mL}$ cupric acetate pyridine. The sample was mixed for $10 \mathrm{~s}$, and then fatty acid content in supernatant phase was measured by spectrophotometer at $715 \mathrm{~nm}$ [12]. Hydrolytic activity of the immobilized lipase was defined as $\mu$ moles of free fatty acid formed per min per g matrix.

\subsection{Assay of esterification activity}

The esterification activity of the immobilized lipase was determined using ethanol and oleic acid as substrates. About 0.1 $\mathrm{g}$ the immobilized lipase was added into a mixture $0.05 \mathrm{M}$ ethanol in isooctane and 0.05 $\mathrm{M}$ oleic acid in isooctane. Mixture was incubated at $60{ }^{\circ} \mathrm{C}, 150$ stroke/min for $20 \mathrm{~min}$. The reaction was stoped by cooling the mixture in ice bath. Fatty acid was determined using spectrophotometer at $715 \mathrm{~nm}$ [12]. The esterification activity of the immobilized lipase was defined as $\mu$ moles of ester formed per min per g matrix. 


\subsection{Optimization conditions for esterification}

The esterification of fructose and oleic acid, which was catalyzed by the immobilized lipase, was performed at $60^{\circ} \mathrm{C}$. The reaction was conducted in a flask containing substrate molar ratio fructose : oleic acid of 1:6 in the presence of $0.5 \mathrm{~g} \mathrm{Na} \mathrm{SO}_{4}$. The reaction was started by mixing fructose and oleic acid with magnetic stirrer for $6 \mathrm{~h}$ at $60{ }^{\circ} \mathrm{C}$. Various amounts of the immobilized lipase $(2,4,6,8$, and $10 \% \mathrm{w} / \mathrm{w})$ were evaluated to get the maximum esterification yields, then various time of esterification (6-72 h) was conducted at the best amount of the immobilized lipase. The yields were determined as mole fructose oleic ester per mole fructose that was initially added to the reaction medium.

\subsection{Re-usability stability of the immobilized lipase}

The re-usability of the immobilized lipase was evaluated by successive batches of esterification of fructose and oleic acid. The reaction was carried out at $60^{\circ} \mathrm{C}$ for an average time $24 \mathrm{~h}$ for every run. After each run, the immobilized lipase was washed by buffer $\mathrm{pH} 7$ and ethanol to remove unreacted substrates.

\section{Results and Discussion}

\subsection{FT-IR analysis of hydrophobic matrix}

In this research, FT-IR analysis was used to determine some new forming bonds when the matrix was modified with several compounds. Native matrix and PEI have poly-amine group $\left(-\mathrm{NH}_{2}\right)$ as main functional group in their structure, while both glutaraldehyde and PPA have carbonyl group $(-\mathrm{C}=\mathrm{O})$. Imine group $(-\mathrm{C}=\mathrm{N}-)$ was formed when the reaction between amine group and carbonyl group occurred. The infrared spectrum for the stretching vibration of primary aliphatic amine occurred at 3380-3400 $\mathrm{cm}^{-1}$. The bending vibration of primary amine occurs in the wave number 1590-1650 $\mathrm{cm}^{-1}$, whereas the bending vibration of the aromatic ring $(\mathrm{C}=\mathrm{C}$ bond $)$ occurs in the range $1450-1510 \mathrm{~cm}^{-1}$.

A decrease in the peak area of primary amine $\left(\mathrm{NH}_{2}\right)$ for stretching vibration occurred at wavenumber $3400 \mathrm{~cm}^{-1}$ (Figure 1). It was followed by the newly formed peak at wave number $1667 \mathrm{~cm}^{-1}$. This peak was the vibration of imine bond $(-\mathrm{C}=\mathrm{N}-$ ). An increase in the peak area also occurred at wave number $1456 \mathrm{~cm}^{-1}$, which was the bending vibrations of the $\mathrm{C}=\mathrm{C}$ bond of aromatic ring. It indicated that the reaction between the primary amine and the carbonyl group $(\mathrm{C}=\mathrm{O})$ of PPA occurred. An increase in peak of the bending vibrations of the $\mathrm{C}=\mathrm{C}$ was occurred due to aromatic rings of PPA. However, only aromatic ring of PPA was responsible for a hydrophobic character of the modified matrix surface. Thus the modification of the matrix surface to obtain the HM was successfully carried out based on FT-IR analysis.

\subsection{FT-IR analysis of hydrophilic- hydrophobic matrix}

Figure 2A is the FTIR spectra of matrix after pretreatment with buffer $\mathrm{pH} 12$. The first step of matrix modification was reaction between matrix and glutaraldehyde. Glutaralde-

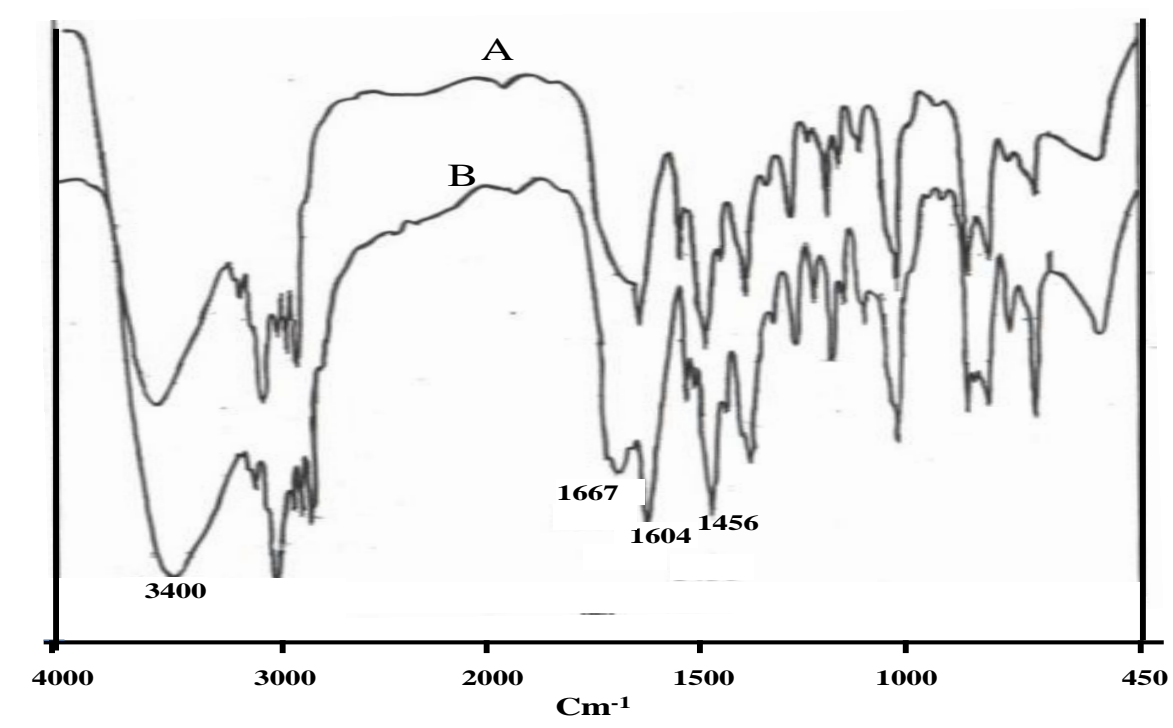

Figure 1. FT-IR spectra of matrix that was pretreated by buffer pH 12 (A) and hydrophobic matrix that was modified by the addition of 2-phenylpropionaldehyde (B) 
hyde was used as a spacer arm for the attachment of PEI on the matrix. Primary amine of the matrix reacted with one end of aldehyde groups of glutaraldehyde. It resulted in a decrease in peak area of stretching vibration of primary amine bond $\left(3398 \mathrm{~cm}^{-1}\right)$ of matrix (Figure 2B). As a consequence a peak of imine bond vibration $(-\mathrm{C}=\mathrm{N}-)$ occurred at $1679 \mathrm{~cm}^{-1}$. It indicated that the attachment of glutaraldehyde on the matrix was successfully carried out.

The second step was reaction between the obtained matrix and PEI, which had a branched structure and high molecular weight $(\sim 25000 \mathrm{Da})$. PEI was used to provide hydrophilic character. The results show that the peak area of the stretching vibration of primary amine bond increased at wave number $\sim 3400$ $\mathrm{cm}^{-1}$ (Figure 2C), when it was compared with the obtained matrix after glutaraldehyde reaction. An increase in a peak area also occurred at $\sim 1606 \mathrm{~cm}^{-1}$, which was a bending vibration of primary amine bond. It indicated that PEI was successfully bound to the matrix.

The last step of matrix modification was the reaction between the obtained matrix and PPA to provide hydrophobic character. PPA has both the aldehyde group end and the aromatic ring end. Aldehyde group bound to the unbound primary amine of PEI. A decrease in the peak area of stretching vibration of primary amine bond occurred at wave number $\sim 3391 \mathrm{~cm}^{-1}$, whereas an increase in the peak area of the vi- bration of $-\mathrm{C}=\mathrm{N}-$ and $\mathrm{C}=\mathrm{C}$ bonds occurred at $\sim 1667 \mathrm{~cm}^{-1}$ and $\sim 1453 \mathrm{~cm}^{-1}$, respectively. An increase in peak area at $\sim 1453 \mathrm{~cm}^{-1}$ was due to the vibration of $\mathrm{C}=\mathrm{C}$ bonds of the aromatic ring of PPA.

\subsection{Effect of $\mathrm{NaCl}$ on the adsorbed lipase on matrices}

The various $\mathrm{NaCl}$ concentrations of buffer $\mathrm{pH}$ 7 were used to optimize the adsorption of lipase into matrix. For HM, an increase in $\mathrm{NaCl}$ concentration to $0.5 \mathrm{M}$ resulted in an increase in protein adsorption about 2.1 times (Figure 3). The adsorbed lipase increased about 1.2 times. Further increase in $\mathrm{NaCl}$ concentration to $2 \mathrm{M}$ resulted in a decrease in both the adsorbed protein and lipase. Thus the optimum $\mathrm{NaCl}$ concentration for lipase adsorption at HM was obtained in buffer $\mathrm{pH} 7$ containing $0.5 \mathrm{M} \mathrm{NaCl}$. For HHM, an increase in $\mathrm{NaCl}$ concentration to $0.5 \mathrm{M}$ resulted in a decrease in the protein adsorption about 1.8 times. Protein was not adsorbed when $\mathrm{NaCl}$ concentration increased to 1 M.

It is suggested that the presence of $\mathrm{NaCl}$ increased the free energy of the proteins and this change in free energy was proportional to the hydrophobicity of the enzyme surface area. When HM was introduced into system, enzyme bound to matrix because it minimized the surface contact area of enzyme in medium containing salt and produced minimum increase in free

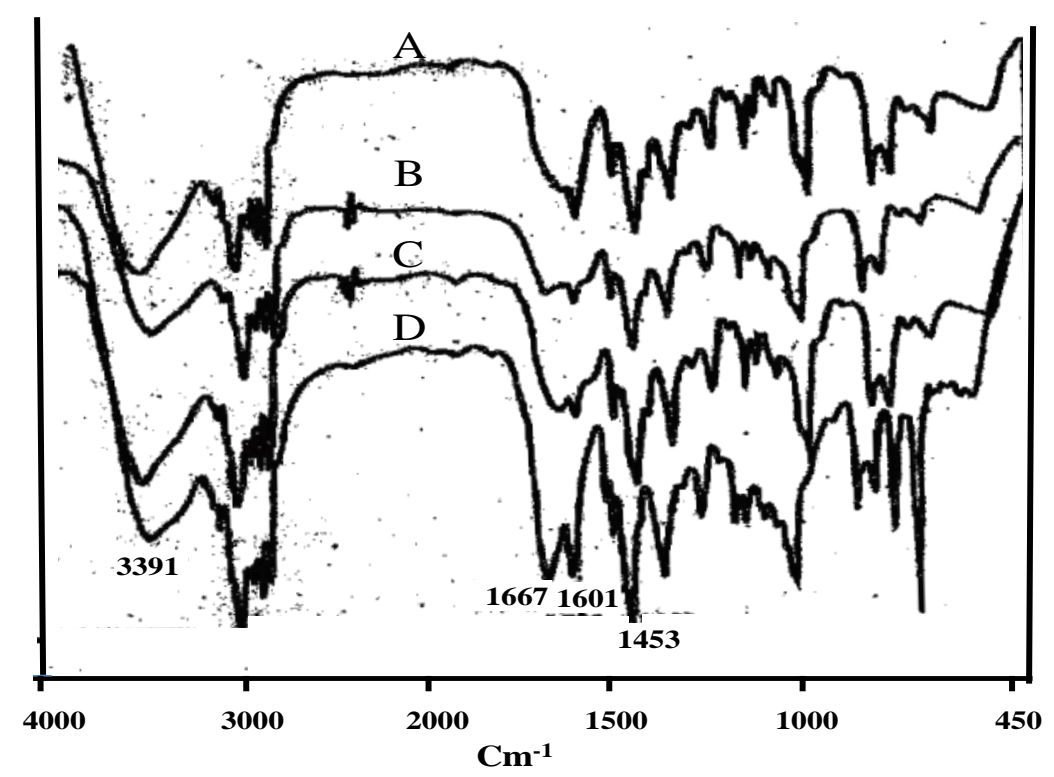

Figure 2. FT-IR spectra of the pretreated matrix with buffer $\mathrm{pH} 12$ (A). First step of matrix modification was the reaction between amine group of matrix and glutaraldehyde (B). Second step was the reaction between the attached glutaraldehyde on matrix and polyethyleneimine (C). The final step was the reaction between amine group of the attached polyethyleneimine on matrix and 2phenylpropionaldehyde 
energy [13]. This explains that HM needed higher salt concentration for immobilization of lipase than HHM. But, if the salt concentration was too high, it caused desorption of the adsorbed protein. HHM did not need salt addition to achieve maximum lipase adsorption.

\subsection{Effect of adsorption time on the ad- sorbed lipase on matrices}

For HM, protein adsorption was fast. Protein was adsorbed $3.9 \mathrm{mg} / \mathrm{g}$ matrix after 15 min (Figure 4). An increase in the adsorption time to $2 \mathrm{~h}$ resulted in an increase in the adsorbed protein about 2.4 times. It was also for the adsorbed lipase. Lipase was adsorbed about $79 \mathrm{U} / \mathrm{g}$ matrix after $15 \mathrm{~min}$. Further increase in adsorption time did not have significant increase in the adsorbed lipase. For HHM, protein was adsorbed $3.01 \mathrm{mg} / \mathrm{g}$ matrix after $15 \mathrm{~min}$. Lipase was adsorbed about $70 \mathrm{U} / \mathrm{g}$ matrix after $15 \mathrm{~min}$. An increase in the adsorption time to $2 \mathrm{~h}$ resulted in an increase in the adsorbed protein about 3.1 times. Further increase in adsorption time did not have a significant increase in the adsorbed lipase. Thus the best lipase adsorption was achieved when lipase was adsorbed for $2 \mathrm{~h}$. Both of matrix types had the same result for the best adsorption time.

\subsection{Effect of the amount of the immobi- lized lipase on fructose oleic ester yield}

Various amounts of the immobilized lipase were used to obtain the best yield of fructose oleic ester (FOE). An increase in the amount of the immobilized lipase from 2 to $8 \%$ resulted in

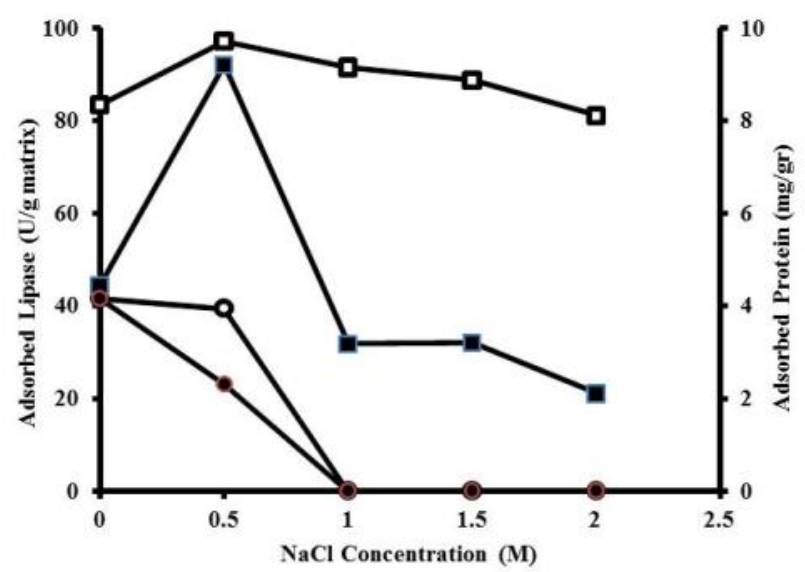

Figure 3. Effect of $\mathrm{NaCl}$ concentration on the adsorbed lipase on hydrophobic matrix ( $\square$ ) and hydrophilic-hydrophobic matrix (o) and the adsorbed protein on hydrophobic matrix (घ) and hydrophilic-hydrophobic matrix (•). Adsorption was performed at $37^{\circ} \mathrm{C}$ for $1 \mathrm{~h}$. an increase in the FOE yield about 2 times for HM (Figure 5). Further increase in the amount of the immobilized lipase did not have significant increase in product yield. Thus the best yield was achieved at $8 \%$ the immobilized lipase (w/w). For HHM, an increase in the amount of the immobilized lipase from 2 to $6 \%$ resulted in an increase in the FOE yield about 3.3 times. Further increase in the amount of the immobilized lipase did not have significant increase in product yield. The best yield was achieved at $6 \%(\mathrm{w} / \mathrm{w})$. The yields of FOE were $75.96 \%$ and $57.74 \%$ for $\mathrm{HM}$ and HHM, respectively.

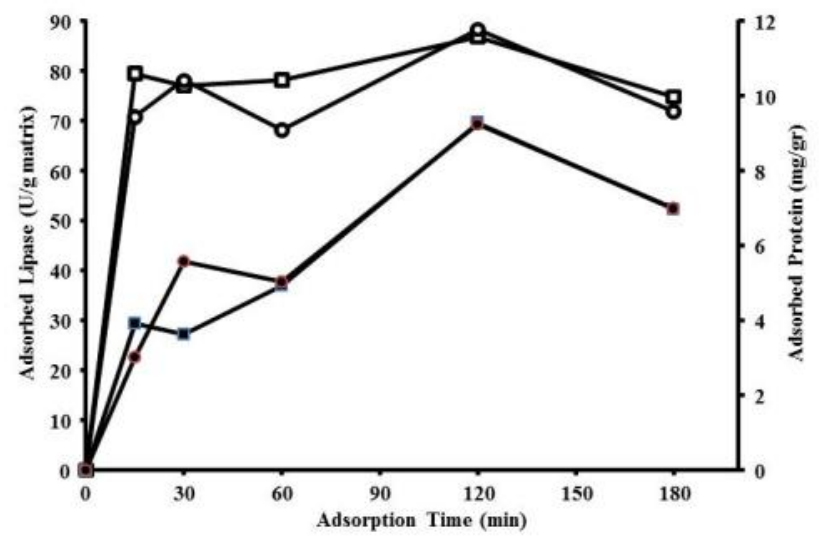

Figure 4. Effect of the adsorption time on the adsorbed lipase on hydrophobic matrix ( $\square$ ) and hydrophilic-hydrophobic matrix (o) and the adsorbed protein on hydrophobic matrix and (a) hydrophilic-hydrophobic matrix (•). Adsorption was performed at $37^{\circ} \mathrm{C}$ and lipase concentration $10 \%$.

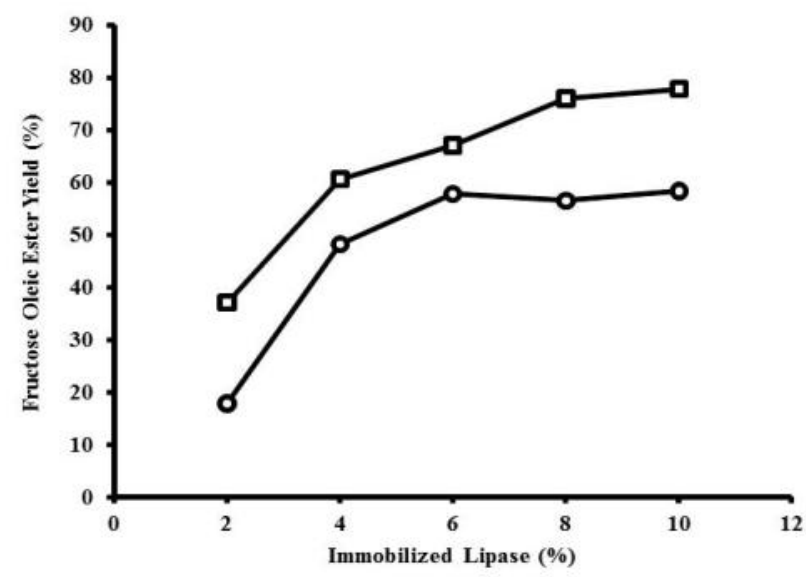

Figure 5. Effect the amount of immobilized lipase on hydrophobic matrix ( $\square$ ) and hydrophilichydrophobic matrix (०) on fructose oleic ester yield. Reaction was performed at $37^{\circ} \mathrm{C}$ for $24 \mathrm{~h}$ 


\subsection{Effect of reaction time on fructose oleic ester yield}

For HM, an increase in reaction time to 24 $\mathrm{h}$ resulted in an increase in the FOE yield to $75.9 \%$. Further increase in reaction time to 48 $\mathrm{h}$ did not have a significant increase in yield. But further increase in reaction time to $72 \mathrm{~h}$ resulted in a decrease in yield about 1.3 times. For HHM, an increase in reaction time to $18 \mathrm{~h}$ resulted in an increase in yield to $85.3 \%$. Further increase in reaction time to $36 \mathrm{~h}$ resulted in a decrease in yield about 2.6 times. It is suggested that a decrease in yield may be caused by hydrolysis of the forming product because water is produced as by-product in the system during reaction. The produced water will interact with the attached PEI. Therefore it enhances hydrolysis reaction. The best reaction time for HM and HHM was $24 \mathrm{~h}$ and $8 \mathrm{~h}$, respectively.

\subsection{Reusability of the immobilized lipase}

In this study, the re-usability of the immobilized lipase was evaluated by successive batch esterification at $60{ }^{\circ} \mathrm{C}$ for $24 \mathrm{~h}$ for every run. The process was repeated up to 3 cycles (Figure 7). After 3 cycles, the FOE yield decreased slightly. The yield was still higher than $93 \%$ when it was compared with first cycle. The results indicated that the immobilized lipase was still stable after 3 cycles.

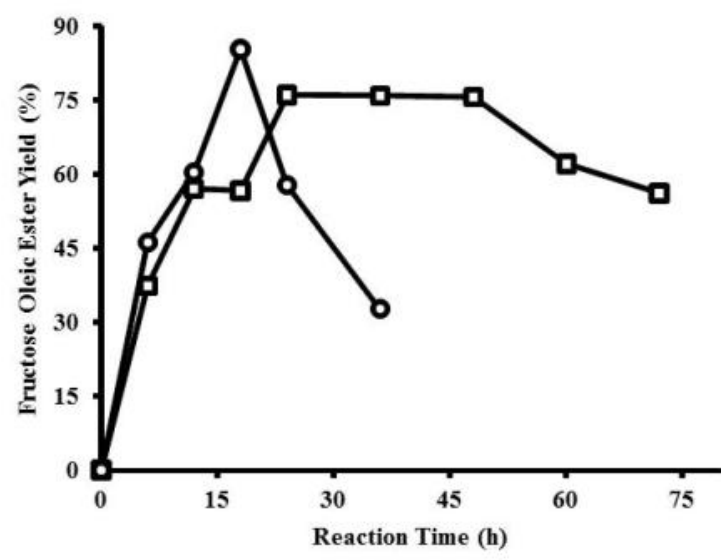

Figure 6. Effect of reaction time on fructose oleic ester yield using the immobilized lipase on hydrophobic matrix (口) and hydrophilichydrophobic matrix (o) Reaction was performed at $37^{\circ} \mathrm{C}$ and the amount lipase of $10 \%$

\section{Conclusions}

For HM, newly formed peak area of the imine bond $(-\mathrm{C}=\mathrm{N}-)$ vibration and an increase in the bending vibrations of the $\mathrm{C}=\mathrm{C}$ bond indicated that the attachment of PPA on the matrix surface to obtain the hydrophobic character was carried out. For HHM, an increase in the peak area of the stretching and bending vibration of primary amine bond indicated that PEI was bound to the matrix. The matrix with hydrophobic surface adsorbed lipase higher than hydrophilic-hydrophobic surface. The FOE yield for HM and HHM were $75.9 \%$ and $85.3 \%$, respectively. It is suggested that the produced water during reaction will interact with the attached PEI and may cause a sharp decrease in yield at an increase in reaction time to $36 \mathrm{~h}$. Yield was still higher than $93 \%$ when it was compared with first cycle. The results indicated that the immobilized lipase was still stable after 3 cycles.

\section{Acknowledgement}

This research was supported by Kementerian Riset, Teknologi dan Pendidikan Tinggi of Indonesia through Penelitian Unggulan Perguruan Tinggi (PUPT).

\section{References}

[1] Shi, Y.G., Li, J.R., Chu, Y.H. (2011). Enzyme Catalyzed Regioselective Synthesis of Sucrose-Based Esters. Journal of Chemical Technology and Biotechnology, 86: 1457-1468.

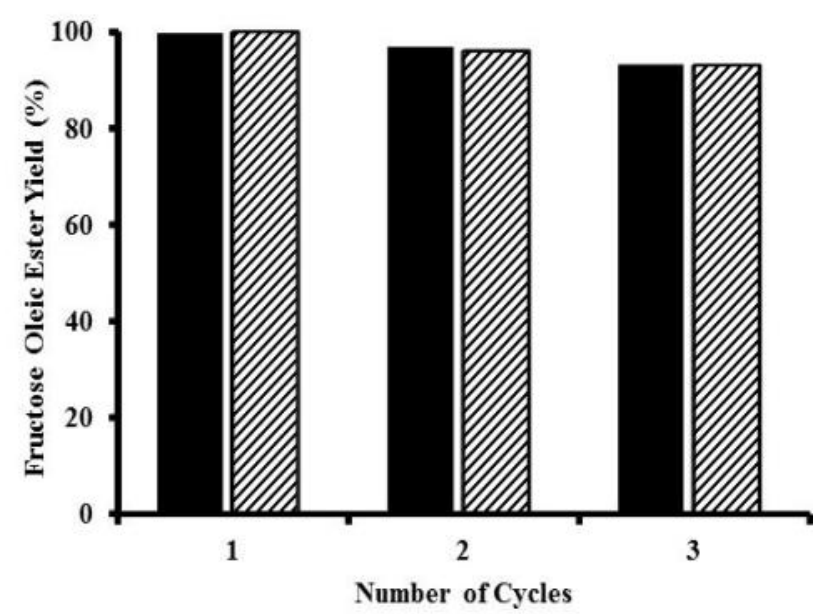

Figure 7. Reusability of the immobilized lipase on hydrophobic matrix (घ) and hydrophilic-

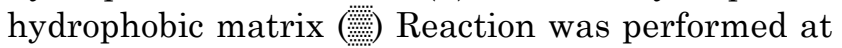
$37 \mathrm{C}$ for $24 \mathrm{~h}$ 
[2] Ye, R., Hayes, D.G. (2011). Optimization of Solvent-Free Lipase-Catalyzed Synthesis of Saccharide-Fatty Acid Esters through Control of Water Concentration. Journal of the American Oil Chemists Society, 88(9): 1351-1359.

[3] Coulon, D., Girardin, M., Rovel, B., Ghoul, M. (1995). Comparison of Direct Esterification and Transesterification of Fructose by Candida antartica Lipase. Biotechnology Letters, 17: $183-186$.

[4] Bastida, A., Sabuquillo, P., Armisen, P., Fernandez-Lafuente, R., Huguet, J., Guisan, J. M.A. (1998). Single Step Purification, Immobilization, and Hyperactivation of Lipase via Interfacial Adsorption on Strongly Hydrophobic Supports. Biotechnology and Bioengineering, 58: 486-493.

[5] Fernandez-Lafuente, R., Armisen, P., Sabuquillo, P., Fernandez-Lorente, G., Guisan, J. M. (1998). Immobilization of Lipases by Selective Adsorption on Hydrophobic Supports. Chemistry and Physics of Lipids, 93: 185-197.

[6] Oladepo, D.K., Halling, P.J., Larsen, V.F. (1995). Effect of Different Supports on The Reaction Rate of Rhizomucor miehei Lipase in Organic Media. Biocatalysis and Biotransformation, 12: 47-54.

[7] Palomo, J.M., Munoz, G., Fernandez-Lorente, G., Mateo, C., Fernandez-Lafuente, R., Guisan, J.M. (2012). Interfacial Adsorption of Lipases on very Hydrophobic Support (Octadecyle Sepabeads): Immobilization, Hyperactivation, and Stabilization of the Open Form of Lipase. Journal of Molecular Catalysis B: Enzymatic, 19-20: 279-286,.
[8] Derewenda, U., Brzozowski, A.M., Lawson, D.M., Derewenda, Z.S. (1992). Catalysis at the Interface: The Anatomy of a Conformational Change in a Triglyceride Lipase. Biochemistry, 31: 1532-1541.

[9] Mateo, C., Palomo, J.M., Fernandez-Lorente, G., Guisan, J.M., Fernandez-Lafuente, R. (2007). Improvement of Enzyme Activity, Stability and Selectivity via Immobilization Techniques. Enzyme and Microbial Technology, 40(6): 1451-1463.

[10] Yan, Y.C., Bornscheuer, U.T., Stadler, G., Lutz-Wahl, S., Otto, R.T., Reuss, M., Schmid, R.D. (2001). Regioselective Lipase Catalyzed Synthesis of Glucose Ester on a Preparative Scale. Journal of the American Oil Chemists Society, 78: 147-152.

[11] Kordel, M., Hofmann, B., Schomburg, D., Schimid, R.D. (1991). Extracellular Lipase of Pseudomonas sp strain ATCC 21808. Purification, Characterization, Crystallization, and Preliminary-X-ray Diffraction Data. Journal of Bacteriology. 173: 4836-4841.

[12] Djagal, W.M., Retno, I., Yoshiyuki, O. (1998). A simplified Method for Determination of Free Fatty Acids for Soluble and Immobilized Lipase Assay. Indonesian Food and Nutrition Progress, 5: 79-83.

[13] Queiroz, J.A., Tomaz, C.T., Cabral, J.M.S. (2001). Hydrophobic Interaction Chromatography of Proteins. Journal of Biotechnology, 87: 143-159. 